\title{
WHAT SINAMA LANGUAGE IS THIS? LANGUAGE FEATURES AND SIMPLE METHODS TO HELP THE NON-LINGUIST NAVIGATE THE SINAMA LANGUAGES AND DIALECTS
}

\author{
Luke Schroeder \\ Graduate Institute of Applied Linguistics (Dallas International University), U.S.A \\ Kauman Sama Online \\ (Luke-Ruth@sinama.org) \\ DOI: https://doi.org/10.22452/brj.sp2019no1.11
}

\begin{abstract}
The Sama have proven over and over again difficult to classify. Non-Sama have called them Badjaw, Samal, and Siyamal. Some Sama have refused to identify with the name Sama and call themselves only by the name of their places of origin. Others have found benefit to identify with the names given them by outsiders. Others have blended in with the Tausug people. As the Sama people have spread across the Philippines and Malaysia, Sama groups may experience reduced contact with other once neighboring or intermingled Sama groups. This paper gives practical though imperfect litmus test examinations that are of use to a cultural observer or those of Sama heritage in identifying which language and dialect of Sinama a conversant or text is written in. The paper focuses on giving meaning to four Sama-Badjaw language classifications and identifying surface level differences that exist among these languages as well as helping to pinpoint various dialects and under which language classification they fit best. The four languages are Northern, Central, Western, and Southern Sinama. Differences in vowel sounds, pronoun usage, language affixation and vocabulary are used to identify language category as well as give insight into what dialect of a language is being spoken. The paper is intentionally abbreviated and simplified in order to make it possible for non-linguists and even those with very simple knowledge of Sinama to make use of its findings.
\end{abstract}

Keywords: Sama, Sinama languages, Sinama dialects

\section{Identity confusion of the Sama}

At a government hospital in Davao, Babu' approaches Social Services, hoping to receive help from government programs for her hospital bill. She should qualify as an indigent. She is a Sama. The Sama are boat people, natives of Sulu but visitors and residents of Davao since at least the time that the first Mindanaon Muslim tribes 
adopted Islam. The name Sama is not recognized by the workers (Kauman Sama Online, 2012). Others in the past have called the Sama Samal. Saying she is Samal is confusing. In Davao the worker is more likely to think Babu' comes from Samal island (the island is actually named after the Sama) than to know this name for her people. She could say that she is Badjao. The Badjao are also Sama. They are Sama Dilaut (references the sea as their place of origin). In Davao, the Sama Dilaut are known mainly for begging. Babu' is a Sama Silompak (Silompak is an island near Siasi, Sulu). Even though the local government has done much to help the Sama Dilaut get access to free healthcare, Babu' is too proud to allow herself to be identified as Badjao. We wish that the simple question of what indigent group Babu' is from could be answered with one sentence. Instead, I am going to write a whole paper about it.

This confusion on who the Sama are does not only exist among social and government workers. There is confusion among the Sama themselves. Sama from Laminusa Island in Siasi have been living in Digos, Davao del Sur for several generations now. I asked a little Sama boy in the Sinama language if he knew how to speak Sinama. He answered me back in Sinama, "Ngga'i. Ata'u aku maglaminusa." (" Not so! I know how to speak Laminusa.") In his community in Digos, they have begun to define Sama solely as the traditionally nomadic Sama Dilaut. They know their languages are similar, but do not want to be associated as such. They have begun to lose their connection to the spaces and places where a variety of Sama speakers with different dialects and islands of origin interact with each other. Now when they come into contact with other Sama who are not Sama Dilaut and not from Laminusa, they are confused on how to classify them.

Another option is that we think we understand the various types of Sama, where they come from, what their languages are like, their culture, but it is easy to accidentally make incorrect associations. I remember talking with a leader of the Sama Dilaut in Isla Verde, Davao City about the varieties of Sama. He was certain on how to classify my wife's language of Sinama (my wife is a Sama from Siasi, Sulu). He said, "I know very well Nde's type of Sama. She speaks Sibutu', the Sama that say, gine'en." Sibutu' is an island in Tawi-Tawi far to the south of where my wife is from. The language there is classified as Southern Sama. Gine'en is a clear indicator of a speaker of Sinama Kabinga'an, a group from an island near Jolo, Sulu!

I do not mean to criticize this leader. In fact, in attempting to write this paper, I run the same risk as he in making incorrect associations. Gathering data from each and every island the Sama come from is next to impossible. A lot of my linguistic data depends on sources living outside of the Sama homelands. Parts of this paper depend on individual Sama knowing the differences between their Sinama and that of the neighboring Sama. If they are wrong, then so am I. They may have biases or misconceptions towards other Sama. In my time of fieldwork with the Sama I may have developed some of my own. Filtering out how intermarriage, frequent movements, and contact with other Sama groups affect the language of individuals 
also complicates this research considerably. I have discovered that the Sama themselves find this topic quite interesting and have much to say on it. Much has been said on it, little has been written on it.

What this Sama Dilaut leader, this Laminusa boy, and this Babu' from Silompak do not realize is that all of their languages are classified linguistically as Central Sinama. Because their languages have quite a few differences, upon hearing that a Sama from one of the other groups is classified as a Central Sama, immediately they might even assume that they must be a Southern Sama or be a Northern Sama. If this is still a matter of confusion for the Sama themselves, how much more confusing it must be for outsiders trying to interact with the Sama.

\section{Linguistic classifications of the Sama}

One of the best methods to differentiate between and compare the Sama is by their language. Linguistic analysis has determined 9 separate but related Sama-Badjaw languages. Grouping these languages in this fashion helps us understand which groups interact with each other and where we can expect to find similarities in speech and grammar. The reality is that the 9 languages are not much like 9 distinct boxes. Instead the Sama-Badjaw languages are a continum. Dialects found near the geographical boundaries that comprise the North, South, Central, and West designations may be a mixture of grammar, vocabulary, and sounds from two Sama languages.

I will only attempt to describe and differentiate between four of the nine SamaBadjaw languages. These are Central Sinama, Sama Bāngingi' (Northern Sinama), Sama Pangutaran (Western Sama), and Southern Sama. This is primarily based off of familiarity. I am most familiar with Central Sinama. I have lived and done language learning in a Sama community in Davao with a mixture of Sama Silompak and Sama Laminusa. There were Sama Kabinga'an and Sama Punungan communities approximately $1 \mathrm{~km}$ in each direction up the coast. I also made friends with and frequently visited Sama Dilaut communities in the Davao area. More recently I have connected with a community in Sarangani composed primarily with Sama from Musu' but also having other Sama Siasi from Manubal, Sibaud, Laminusa, and Sisangat intermixed into the community. Nearby there are Sama Kaulungan, Sama Kabinga'an, and Sama Dilaut. All of these dialects aside from Sama Kaulungan are classified as Central Sinama dialects.

Did I fail to mention that I am married to a Sama from Siasi, Sulu? This would of course account for my greater familiarity with Central Sinama since Siasi Sama speak Central Sinama, but it is also through my wife's family network that I have connections to Sama Pangutaran, Sama Bāngingini' and Southern Sama. Data and observations from these three languages were primarily obtained through these family connections, the few friends I have made along the way in Zamboanga, Tawi-Tawi, 
Semporna, and Sandakan, and the existing literature and dictionaries written in these languages.

\section{Explanation of some of the categories}

\section{Who are the Badjaw?}

Well that depends. Most Filipinos spell it 'Badjao' and Malays spell it 'Bajau' and the reason for this is that the national languages of the Philippines and Malaysia do not have compatible sound systems (Schroeder, 2017, pp. 4, 8). The two spellings of the same word sound exactly the same when pronounced. The spelling 'Badjaw' will be used henceforth in this paper giving preference to the sound system of the Sama languages over that of Filipino or Malay sound systems. When a Filipino refers to the Badjaw, he is specifically thinking of the Sama Dilaut. Among themselves, the Sama Dilaut just call themselves Sama, but for recognition purpose and possibly because of the connotation, they will often refer to themselves as Badjaw to others (Kauman Sama Online, 2013). Other Filipino Sama tend to think of themselves as distinctly different from the Sama Dilaut and generally do not want to be called Badjaw. This can cause confusion with the linguistic classifications since the dialects of the Sama from Siasi, as well as a few of the islands from the northern part of Tawi-Tawi are not themselves Sama Dilaut, but their dialects are classified as Central Sinama along with the Sama Dilaut.

The Sama in Malaysia are a mixture of citizens and immigrants. In Malaysia the term Badjaw has become an overarching name for all of the Sama languages discussed in this paper as well as for the West-Coast Bajau and the Jama Mapun. The term has been accepted by the Malay population and the Sama populations themselves (Kauman Sama Online, 2013). Sama who were born in the Philippines and migrated also adopt the term quickly.

The Malaysian use of the term Badjaw will not be very helpful in separating out the different languages since Badjaw can refer to 6 languages that exist in Sabah. In the Filipino concept of the word Badjaw, all of the Sama who belong in this classification are a dialect within the language Central Sinama. This is true from Sitangkai, Tawi-Tawi all the way up to Batangas in Luzon.

\section{Sama Dilaut and Sama Deya}

This is the category system that many Sama Dilaut use. It is an "us and them" category used by the Sama Dilaut to describe other Sama groups as being different from themselves. Once again it can be useful in identifying members of a dialect group within the Central Sinama language, but it can be misleading to an outside observer. The word dilaut refers to the sea and the word deya refers to inland. The shoreline does not fall within the meaning of either word and most Sama build their homes on the shoreline. Many Sama harvesters of sea weeds live in homes on tidal flats with no 
visible connection to land. Most of these Sama would be classified by Sama Dilaut as Sama Deya. Conversely in the Philippines it is very rare anymore to find Sama Dilaut living on houseboats. In fact, in some areas you will find Sama Deya homes extending far out on bridges over the water and the Sama Dilaut homes are on the shore but do not extend over the water.

It is also worth adding a few additional terms used to mark this distinction between Sama Dilaut and Sama Deya. Some Sama refer to the Sama Pagūng 'floating Sama' referring to the Sama Dilaut and the Sama Paosol 'Sama who use stilts for their homes' referring to those that are not Sama Dilaut. This classification is hardly helpful as most of the Sama Dilaut have abandoned their houseboats.

In the Siasi area the non-Sama Dilaut groups are referred to as Sama Lipid and the Sama Dilaut call themselves the Dì Sama, meaning the pure or genuine Sama or the Sama to'ongan, meaning they are truly Sama. Siasi groups hold onto the memory of the Sama Lipid term and it is useful, but it is not known in Tawi-Tawi and towards Zamboanga. Because being pure or genuine is a judgment call, it is one that only the Sama Dilaut use for themselves.

\section{Bajau Laut and East Coast Bajau}

This dichotomy between Sama Dilaut and Sama Deya is a specifically critical concept for the academics and those in media to understand when considering the Malaysian context. Because there is a West Coast Bajau language of a people with a culture more land oriented than the ocean-oriented Bajau, it follows that a corresponding term is needed to describe this other group. Bajau Laut could easily be confused as that term since all of the Sama are orang laut 'people of the sea'. For the sake of understanding on both sides of the border, I would propose that Bajau Laut should be a term reserved for the boat dwelling group including those who have in the past lived in boats as well as their descendants. Several of the Sama that have been featured in film by the likes of BBC or in the film festivals are described as Bajau Laut but clearly both linguistically and genealogically have connections to groups that fall under the description of the term 'Sama Deya' as used by the Sama Dilaut.

A more appropriate term to describe this sea oriented Bajau on the east coast of Sabah is to refer to them as East Coast Bajau. This term also is not particularly helpful in accounting for the smaller linguistic and cultural divisions within the Sama people. The West Coast Bajau categorization refers to a specific language. East Coast Bajau is comprised of multiple languages. The languages that comprise East Coast Bajau still exist on both sides of the Philippines and Malaysian border and intelligibility within each individual language remains high.

From my vantage point these two words have caused confusion even among the linguists and may have affected the anthropological literature concerning the Sama Dilaut. Sather describes the Bajau Laut of Bangau-Bangau as speakers of the Southern Sama language and he bases this on a paper about the East Coast Bajau languages 
written by Walton and Moody in 1984. Walton and Moody (1984) seem surprised that the wordlists from Siasi and Sitangkai in the Philippines are so similar. However, since the Sama in Sitangkai are Sama Dilaut, it should be expected that their language is Central Sinama. Using principles in this paper and a few of the Sinama words included in Sather's work, I can make an argument that the Bajau Laut he did his research among were Central Sinama speakers. Walton and Moody's data and conclusion conflict with that of Kenneth Smith's data for East Coast Bajau that they reference in their work. Neither paper seems to clearly understand the language divisions of the Sama languages as they exist today. I assume that trying to lump everything under the category of East Coast Bajau is partially what complicates the issue.

\section{The Sama Bāngingi' classification}

Sama Bāngingi' is the prestige dialect of the Northern Sama language to the extent that the Ethnologue calls the entire language Sama Bāngingi'. There are many dialects that may present themselves to others as Sama Bāngingi' presumably because the Bāngingi' group is probably the second most recognized Sama group in the Philippines, second only to the Sama Dilaut. Most likely Bāngingi' recognition stems largely from their strong resistance against the Spanish. Many Sama would prefer the respected or at least feared warrior image of the Bāngingi' than the marginalized image that the Sama Dilaut have in greater Philippine society. A Kaulungan informant told me that the way he explains what language and people he is from depends on who is asking. If a soldier or policeman is asking, he says he is badjaw in order to avoid suspicion and to immediately conveys the stereotype of the badjaw being peace loving. If a Tausug is asking, he will tell them he is a Bāngingi' for the brave image that the term Bāngingi' conveys. My Kaulungan friend knows he is neither, but who wants to take a half hour trying to explain to someone who you are?

Many of the dialects on the boundary line of the Northern and Central Sama classification may present themselves as Sama Bāngingi'. I have observed Sama Laminusa, Sama Kabinga'an and Sama Kaulungan speakers do this. Further investigation proved they were not Sama Bāngingi'. I would classify Laminusa and Kabinga'an as Central Sinama and Kaulungan as belonging to the Sama Bāngingi' language. The Ethnologue classifies Kabinga'an as a dialect of Sama Bāngingi' and Pallesen (1985) in his work includes the Kaulungan dialect as Central Sinama even though it is a Basilan Sama language.

The distinction between the languages included as Sama Bāngingi' and Central Sinama are even more sociological and historical than they are linguistic. I'm told there used to be a Bāngingi' outpost on Laminusa island (interview with Pallesen, April 11, 2018). Therefore, the language of the Bāngingi' would be familiar to the Sama in this region and even partially adopted by them. However, the history of the Laminusa Sama, their location around the larger island of Siasi, and their 
intermarriage with these Sama of Siasi gives a strong argument for their belonging to the Central Sama classification.

\section{Ascribing dialects to languages}

My goal in this paper is to provide something practical that can be used for the development of Sama language materials as well as help the Sama diaspora understand how they relate to Sama society as a whole and to provide quick guidance for non-Sama as they connect with Sama peoples and communities. As far as language development, the ideal situation is that we could have books, media, apps, and news in all of the dialects. Understanding how the dialects and languages relate with each other serves us well when considering the reality that such language development does not come easy. Just remember that languages at boundary lines are on a spectrum. They will not fit the prototypical description of either language and they may benefit from or find themselves alienated when presented with written or recorded material in dialects towards the center of the language group. I cannot represent all groups due to lack of familiarity.

\section{SAMA BĀNGINGI ${ }^{\circ}$ LANGUAGE Northern Sinama (sse) \\ Lutangan, Sibuku, Pilas, Taluksangay, Tongkil, Boan, Kaulungan}

\begin{tabular}{|l|}
\hline \begin{tabular}{c|} 
SAMA PANGUTARAN LANGUAGE \\
Western Siyama (slm) \\
Pangutaran,Sowang Buna (North Ubian)
\end{tabular} \\
\hline
\end{tabular}

\begin{tabular}{|c|}
\hline CENTRAL SAMA LANGUAGE \\
(sml) \\
Kabingaran, Laminusa, Punungan, Buli \\
Kullul, Silompak, Musu־, Kūd-Kūd, \\
Sibaud, Manubal, Sama Dilaut, \\
Bannaran, Bintawlan, Tabawan
\end{tabular}

\begin{tabular}{|c|}
\hline SOUTHERN SAMA LANGUAGE \\
(ssb) \\
South Ubian, Tandubas, Sapa-Sapa, \\
Simunul, Sibutur, Sikubong, Kubang
\end{tabular}

Pallesen (1985) concludes that Kaulungan and South Ubian are classified as Central Sama (pp. 280-281). I have deferred with him here. I have ascribed Kaulungan as a dialect of Sama Bāngingi' due to their location as well as some of their word choices. I have ascribed South Ubian to Southern Sama based on my limited understanding of their affixation system and grammar. 


\section{Guidelines for using language diagnostic tests}

I must stress that the methods laid before you in this paper are guidelines. Language is too fluid, changes too quickly and has too many idiosyncrasies to turn most of these into laws or rules. Most Sama are multilingual, not just in regional, national, and international languages, but they are multilingual even among the Sama languages. This means that Sama Sibutu' communicate well with Central Sama because they have enough similarities that they can negotiate meaning and also they have familiarity since they have Central Sama communities nearby their home island, especially in Sitangkai. My wife will bend her Central Sinama towards Southern Sama when speaking with Sama Sibutu'. She will bend her dialect towards Laminusa when talking with the Laminusa. Central Sinama is especially widespread due to their high level of mobility.

You will find a lot of these diagnostic tests very hard to accomplish through reading and writing. Attempting these tests is best done audibly. There are several orthographies being used with the different Sama languages. Sama also are not well versed in using these orthographies and may fail to mark key features of their language since the national language orthographies are not adequate for the Sama languages. Consistently I have used a Central Sinama Orthography as I have described on the Kauman Sama Online website and in previous writings. This makes it possible to compare how the languages are similar and different. Because some of this paper's data is based off of written content such as Facebook correspondence and online dictionaries, there is room for possible errors in my data based solely on misspelling or alternative spellings.

It is also good to consider the diagnostic tests as a whole, especially for dialects on the boundaries of two languages. It is very possible that the majority of one dialect's features fit it nicely into one of the Sama language categories but there are a few features that make it more similar to another one of the Sama languages.

\section{Identifying a Sama language by its vowel sounds}

A quick check to identify which Sinama language a Sama speaker is using is listen to their vowel sounds. This method is claimed to be used by Malaysian and Filipino authorities to distinguish between a Tausug and a Sama since Tausug may disguise themselves as Sama. Supposedly the authorities will ask the person what they call a piece of candy. If the speaker can say kendi, they are Sama. If they say kindi, they are Tausug. This works because Tausug have only three to four vowel sounds.

The same type of test can work to try and draw dividing lines between the Sinama languages. Sama Bāngingi' vowels have for the most part reduced to $5<\mathrm{a}\rangle,<\mathrm{e}\rangle$, $<\mathrm{i}>,<\mathrm{O}>$, and $<\mathrm{u}>$ (Manga bissara, 1993). There are a few words like the word $n s a^{\prime}$ 'to not have' which serve as an exception to this rule. The word $n s a^{\prime}$ actually has the $6^{\text {th }}$ vowel $\langle\partial\rangle$ in the word initial position (J. Gault, personal communication, April 16, 
2018). Expect for almost all Sama Bāngingi' words to have shifted their vowel sounds to match one of the initial 5.

Southern Sama has also for the most part had its vowels reduced to the same 5 as Sama Bāngingi' (Allison, E. J., 1979 p. 73). The $6^{\text {th }}$ vowel $<\partial>$ is only used still in the word initial position prior to two consonants and is not written. Some words that include it are bbung 'dolphin', lling 'utterance', llow 'day or sun', and llum 'alive'. Also the sound <ay> as pronounced in Central Sinama becomes <ey> for Southern Sama speakers. Bay 'past tense marker' becomes bey. Subay 'must' becomes subey and so on. The listed Southern Sama examples are from the book entitled Basic Vocabulary (English, Pilipino, Sama Sibutu) compiled by K. J. Allison (1979).

Central Sinama has six vowels. The central vowel $<$ ə $>$ is a lot more common and contrastive in Central Sinama. It is not only present word initial, but also word medial. It has traditionally been spelled with the symbol ['] but is not spelled in the word initial position without a prefix.

In a conversation with a Sama in order to get quick data to help with the vowel sounds check you can ask them about their family. Do they have a husband or a wife? Are their children boys or girls? The response they give will allow you to listen to the vowel sounds and make a quick educated guess at which language grouping they would fall under.

\begin{tabular}{|l|l|l|l|l|}
\hline English Gloss & Southern Sama & Central Sinama & Pangutaran & Bāngingi' \\
\hline husband & {$[$ halla] } & [həlla] & {$[$ həlla] } & [halla/hella] \\
\hline wife & {$[$ handa $]$} & [hənda] & [hənda] & [handa/henda] \\
\hline boy & {$[$ lalla] } & [ləlla] & {$[$ ləlla] } & [lalla/lella] \\
\hline girl & [danda] & [dənda] & [dənda] & [danda/denda] \\
\hline
\end{tabular}

Neither the Southern Sama or Sama Bāngingi' pronunciation of these words has the central vowel. Southern Sama has consistant vowel agreement in words that possess a central vowel in Central Sinama, the Southern Sama pronunciation will match the first vowel with the vowel that follows it.

\begin{tabular}{|l|l|}
\hline Central Sinama & Southern Sama \\
\hline l'bbak 'pothole' & labbak \\
\hline k'ppes 'to deflate' & keppes \\
\hline p'ssi 'fishhook' & pissi \\
\hline s'ddop 'to set (of the sun)' & soddop \\
\hline t'bbu 'sugar cane' & tubbu \\
\hline
\end{tabular}


For the most part Sama Bāngingi' follows the same rule as Southern Sama, except that there are several exceptions for common words. For instance at'ggol 'long time' in Central Sinama is ateggol in Sama Bāngingi'. I have already covered how boy, girl, husband, and wife in some dialects of Sama Bāngingi' do not have vowel agreement.

Sama Pangutaran retains yet an additional 7 th vowel $\langle\gamma\rangle$, that existed in the protosama-bajaw language (Walton, 1979 p. 202). The most effective method for distinguishing Sama Pangutaran from the other three languages discussed in this paper is to listen for the 7th vowel. Here is a list of seven words from the EnglishPangutaran Dictionary (Walton \& Walton, 1992) that are common in other languages but sound different in Sama Pangutaran or words that are frequently used in every day speech: hayōp 'animal', tō'ōd 'really', diyōm 'inside', t'ggōl 'long time', bōd 'mountain', bōntol 'straight', and kōsog 'strong'.

One of the weaknesses of this method for distinguishing between the language boundaries of the Sama languages is that the less vowel sounds in your mother tongue the harder it will be for you to detect the differentiating vowel sounds in the speech of others. Thus a Sama Bāngingi' might not easily recognize that there is a difference in his pronunciation of danda/denda from that of the Central Sinama speaker. Also for some dialects that are on the borders of the language divisions this is not always a clear cut test. A speaker may not even be consistant in how he pronounces.

\section{Identifying a Sama language by its affixes}

Many of the Sama languages share a large portion of root words. However, when using the root words in speech they often have different prefixes or infixes. Because these affixes are found over and over again in speech after carefully listening for which set of affixes are common in a speaker's speech, you can gain clues to help you determine what Sama language a person belongs to.

One of the most effective checks to determine which Sama language a person or a dialect belongs to is to look for the presence of either the -in- or -iy-infix or the niprefix. With this method you can distinguish between three of the Sama languages. The verbal infix -iy- is used soley in Sama Pangutaran: Tiyungbasan ka. In Southern Sama they would say nitungbasan kow. Sama Bāngingi' and Central Sinama both have the -in-infix: tinungbasan ka.

Some word roots in Sama Bāngingi' and Central Sinama use the prefix niinstead of the infix -in-. Some speakers might say dinakdakan 'to wash (of clothes)' others may say nidakdakan. It is much better to determine whether a language might be Southern Sama based on the absence of the -in-infix instead of the presence of the ni- prefix.

Another prefix that can help you determine between language breaks is the presence or absence of the $a$ - prefix found before adjectives. The dialects of Southern 
Sama and Sama Pangutaran would both say hāp and la'at for good and bad. Dialects of Central Sinama and Sama Bāngingi' would say ahāp and ala'at.

There is also a verbal prefix $a$ - that Central Sinama uses in sentences focused on the person acting. This also exists in Sama Bāngingi' but not in Southern Sama and Sama Pangutaran. Some examples of this are atuli (to sleep) compared to tuli, amangan (to eat) compared to mangan, and alahi (to run away) compared to lahi.

There is also a verbal prefix $a N$ - for Central Sinama and Sama Bāngingi' which is rendered $N$ - in Southern Sama and Sama Pangutaran. This is best understood with examples. The root word beya' (to go along with) becomes ameya' with the prefix $a N-$. With just the $N$ - prefix as in Southern Sama the word is pronounced meya'. The root word sulat (to write) becomes anulat and nulat. The root word kambay (to wave) becomes angambay and ngambey. The root word ongka' (to play) becomes angongka' and ngongka'

These two $a$ - prefixes, one for adjectives and one for verbs, along with the $a \mathrm{~N}$ for verbs result in a lot of three syllable words starting with ' $a$ ' in Central Sama and Sama Bāngingi'. There will be very few that are only two syllables. There are a lot of adjectives and verbs in Southern Sama and Sama Pangutaran that are only two syllables. Very few Central Sama and Sama Bāngingi' verbs will start with the nasal consonants $\mathrm{m}, \mathrm{n}$, and ng whereas they are quite common in Southern Sama and Sama Pangutaran.

The prefixes $a$ - and $a N$ - are also the major reason I choose to classify South Ubian as a Southern Sama Dialect. The Sama Ubian say hāp 'good', while all any other dialects in the Central Sama list would say ahāp. Sama Ubian say niya' 'to have', while all the other dialects of Central Sama say aniya'.

I am hard pressed to find grammatical reasons to make a distinction between Central Sinama and Sama Bāngingi'. I would propose that generally Central Sinama uses the mag-prefix or prefers it where dialects of Sama Bāngingi' tend to use or at least prefer the ag-prefix. Some examples of this are magiskul or agiskul, magdakdak or agdakdak. This can get confusing though when we try to draw a hard and fast line. Sociolinguistically the Sama Laminusa sometimes identify with the Bāngingi' and sometimes with the majority of Sama from Siasi who are classified as Central Sama. You may very well hear them using both prefixes. This impression should not be used as a hard and fast rule.

\section{Identifying a Sama language by its pronouns}

The majority of the pronouns used by the Sama languages are the same, but there are minor differences that would help you determine which Sama language a speaker's dialect would fall under.

Here are the Central Sinama actor focused pronouns: 


\begin{tabular}{|l|l|l|}
\hline & SINGULAR & PLURAL \\
\hline First person (I, we) & $a k u$ & $k a m i$ (exclusive) / kitam (inclusive) \\
\hline Second person (you) & $k a / k a^{\prime} a$ & $k a m / k a^{\prime} a m$ \\
\hline $\begin{array}{l}\text { Third person (he, she, } \\
\text { they) }\end{array}$ & Iya & sigā, sigala (dual), sigām, sigalam (many) \\
\hline
\end{tabular}

The third person plural pronoun in Sama Bāngingi' language is rendered siga'am and sometimes sigalam in several dialects. The second person singular pronoun in Sama Pangutaran is $k a^{\prime} u$. The second person singular pronoun in most Southern Sama dialects is kow. Some Southern Sama dialects such as Sama Ubian use $k a$ and $k a^{\prime} a$.

\section{Word Variation Diagnostic Tests}

I will include here some words that are especially helpful for a listener to single out what dialect a speaker is using.

\begin{tabular}{|c|c|c|c|c|c|c|c|c|}
\hline 1. $P \bar{e}^{\prime}$ & 2. Pehē' & 3. Pihī' & 4. $\mathrm{Pa}^{\prime}{ }^{\prime}$ & 5. $\mathrm{P}^{\prime}{ }^{\prime}$ & 6. Pe'e & $\begin{array}{l}7 . \\
\text { Pehelē' }\end{array}$ & $\begin{array}{l}\text { 8. Pilì'/ } \\
\text { Pi'ili' }\end{array}$ & 9. Pahi' \\
\hline \multirow[t]{5}{*}{ Bāngingi' } & $\begin{array}{l}\text { Sama } \\
\text { Dilaut }\end{array}$ & Manubal & Laminusa & Musu' & Sibutu' & $\begin{array}{c}\text { (Sama } \\
\text { Dilaut) }\end{array}$ & Simunul & Pangutaran \\
\hline & Silompak & Sapa-Sapa & Punungan & & & & & \multirow{4}{*}{$\begin{array}{l}\text { North } \\
\text { Ubian }\end{array}$} \\
\hline & \multirow[t]{3}{*}{ Sibaud } & & Buli' Kullul & & & & & \\
\hline & & & Kabinga'an & & & & & \\
\hline & & & Kaulungan & & & & & \\
\hline
\end{tabular}

Parenthesized dialect names means it is a less frequent form for that dialect.

\begin{tabular}{|c|c|c|c|c|c|c|}
\hline \multicolumn{7}{|c|}{ English Gloss 'not so' } \\
\hline \multicolumn{2}{|l|}{ 1. Ngga'i } & 2. Nggara & 3. Duma'in & 5. Me'en & 6. Siraka & 7. Sikeya \\
\hline Kabinga'an & Sibaud & Tabawan & (Laminusa) & Pangutaran & Sapa-Sapa & Sibutu' \\
\hline Laminusa & Silompak & & Musu' & & South Ubian & Simunul \\
\hline Manubal & Kaulungan & & Kaulungan & & Tandubas & \\
\hline Sama Dilaut & Tabawan & & Kabinga'an & & & \\
\hline
\end{tabular}


Parenthesized dialect names means it is a less frequent form for that dialect.

\begin{tabular}{|c|c|c|c|c|c|c|c|c|}
\hline \multicolumn{9}{|c|}{ English Gloss 'like that' } \\
\hline 1. Buwattē' & 2. Bittī' & 3. Battī'/B'tti' & 4. Ingī' & 5. Gin̄̄' & 6. Saili & 7. Saihi' & 8. Salaihi' & 9. Betē' \\
\hline Musu' & Manubal & Musu' & Buli' Kullul & Kabinga'an & Kaulungan & Bāngingi' & 'Bāngingi' & Sibutu' \\
\hline Sama Dilaut & t Sibaud & Silompak & Laminusa & & & & & Simunul \\
\hline Silompak & & & Punungan & & & & & \\
\hline
\end{tabular}

\section{Quick identification words}

Some of the dialects have words or phrases that other Sama identify as characteristic of one specific group. These words can immediately clue in the listener to where a person is from.

\section{Manubal}

For instance, many Sama from Siasi might say something like $N \bar{e}$ Rāng 'wow'. However, the Sama Manubal are known for drawing out that phrase exceptionally long.

\section{Laminusa and Buli' Kullul}

The speech of Sama Laminusa, Sama Punungan, and Sama Buli' Kullul can be quite hard to differentiate. The phrase "E $\bar{E}$ Tuwan $n i$ " is a remark of surprise somewhat like 'wow' that other Sama identify as being said only by those from Laminusa. Those from Buli' Kullul are said to say "Etta na" as a phrase acknowledging a person.

\section{Sibutu' and Simunul}

Those from Sibutu' say tutu as an emphasized form meaning 'this one'. Those from Simunul say iti meaning the same thing.

\section{Sama Dilaut and Tabawan}

The Sama Dilaut are immediately singled out for saying lahi-lahi meaning 'run'. Other Sama Siasi use the phrase paragan. The Sama Dilaut can be differentiated from surrounding Sama because of their use of $h e^{\prime}$ (attributes an action or verb) whereas Sama Tabawan and others say e'. Also the Sama Dilaut use the particle $h \bar{e}^{\prime}$ to reference something already said. Other Sama use $\bar{e}^{\prime}$ or $\bar{\imath}^{\prime}$. 


\section{Bāngingi'}

The Kaulungan differentiate themselves from being Sama Bāngingi'. Many of the Sama groups recognize the Bāngingi' as the group that says ele'. This is referencing something in the distance or the lengthened form of $\bar{e}^{\prime}$. Many Sama Bāngingi' words remain uncontracted while other Sinama languages have already contracted them. Sigalam or siga'am instead of sigām 'them or they'.

\section{Conclusion}

The variety that exists among the Sama languages and dialects and yet the clarity and cooperative ways that Sama are able to communicate with each other across the Southern Philippines and into Malaysia is astounding and sometimes confounding. Classifying is a human need in order to understand. For so long the identity of the Sama has been hard for both outsiders and insiders to the culture to understand. I hope I have not put the Sama into a box. It is not for the sake of unnecessary division or unrealized unity that I have covered these language and dialect classifications. The goal is to unpack the boxes and make it more usable to those who are seeking the development and improvement of their people or working to help the Sama in some fashion.

\section{References}

Allison, E. J. (1979). The phonology of Sibutu Sama: A language of the southern Philippines. Manila: Summer Institute of Linguistics-Philippines. Retrieved from https://www.sil.org/resources/archives/25771

Allison, K. J. (1979). Basic Vocabulary (English, Pilipino, Sama Sibutu). Manila: Summer Institute of Linguistics-Philippines. Retrieved from https://www.sil.org/resources/archives/24402

Kauman Sama Online. (2012, October 23). Case Study for Social Workers: Some Sama would rather die than be called Badjao. Retrieved from https://sinama.org/2012/10/case-study-for-social-workers-some-samawould-rather-die-than-be-called-badjao/

Kauman Sama Online. (2013, January 10). The Bajau, the Badjao, the Samals, and the Sama People. Retrieved from https://sinama.org/about-sama-people/thebajau-and-sama-people/

Manga bissara: Sama Bangingì, Pilipino, English. (1993). Manila: Summer Institute of Linguistics. Retrieved from https://www.sil.org/resources/archives/64501

Pallesen, A. K. (1985). Culture Contact and Language Convergence. Manila: Linguistic Society of the Philippines. 
Schroeder, L. J. (2017). Popularizing a Practical Sinama Orthography Based on its Unique Language Features. Manuscript submitted for publication, Sabah Museum Monograph Volume 14, Department of Sabah Museum, Kota Kinabalu.

Walton, C. (1979). Pangutaran (Sama) Phonology. Studies in Philippine Languages and Cultures. Retrieved from https://www.sil.org/resources/archives/25996

Walton, J. R., \& Moody, D. C. (1984). The East Coast Bajau Languages. In J. King \& J. King (Eds.), Languages of Sabah: A Survey Report (pp. 113-123). Canberra: The Australian National University. doi:10.15144/PL-C78.113

Walton, J. R., \& Walton, C. (1992). English-Pangutaran Sama dictionary. Manila: Summer Institute of Linguistics. Retrieved from https://www.sil.org/resources/archives/25673 